\title{
Dissonance: scientific paradigms underpinning the study of sound in geography
}

\author{
DANIEL PAIVA
}

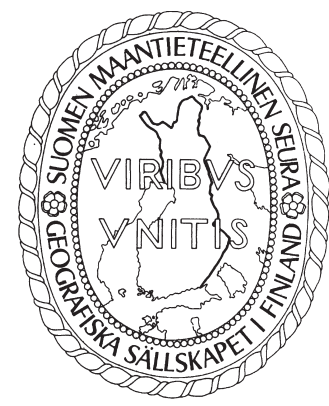

Paiva, D. (2018) Dissonance: scientific paradigms underpinning the study of sound in geography. Fennia 196(1) 77-87.

https://doi.org/10.11143/fennia.69068

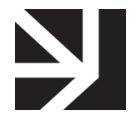

The objective of this article is to approach the different conceptions of sound - and its relations to the underlying scientific paradigms - that emerged throughout the history of geography. There has been a growing interest among geographers in understanding the spatialities of sound, and geographies of sound have become an emerging subfield of the discipline. For this reason, it is the right time to address how the discipline has approached sound throughout its history. Several theoretical perspectives influenced geography in the twentieth century, changing its methodologies and how its subjects were conceived. Sound, like other subjects, has been conceived very differently by geographers of competing paradigms. Concepts such as noise, soundscape, or sound as affect, among others, have dominated geographies of sound at specific periods. Due to the marginality of the subject in the discipline, assessments of these conceptual shifts are rare. I tackle this issue in this article as I provide a first attempt of writing a history of sound in geography. The article reviews debates regarding the name of the subfield, and the conceptions of sound in the successive and competing scientific paradigms in geography.

Keywords: sonic geography, geographic perspectives, noise, soundscape, listening, performance

Daniel Paiva, Centre for Geographical Studies, Institute of Geography and Spatial Planning, Universidade de Lisboa, Rua Branca Edmée Marques, 1600276 Lisbon, Portugal. E-mail: daniel.paiva@campus.ul.pt

\section{Introduction}

More than 20 years ago, Rodaway (1994) adverted geographers to the fact that, despite a growing body of studies, there was little agreement over what a geography of sounds would be called. He distinguished between aural geography, which would be "a sensuous geography derived from the ears" (Rodaway 1994, 84); and sonic geography, which "would refer to the spatial organization of sounds and characteristics of places in terms of sound" (ibid., 84). He also proposed "auditory geographies", which would address "the sensuous experience of sounds in the environment and the acoustic properties of that environment through the employment of the auditory perceptual system" (Rodaway 1994, 84), encompassing both hearing and listening. He did not consider the term acoustic, which has been used by geographers (Gandy \& Nilsen 2014; Revill 2014) and others (LaBelle 2010), generally in a similar manner to what Rodaway called 'sonic geography'. In French geography, the term 'bruit', which can be translated both as sounding or noise, has been employed, along with the term 'geographie des milieux sonores' (geography of sonic milieux or geography of sonic places; for both 
uses, see Roulier 1999). In other communities, 'geography of sounds' has also been used (Alves 2016), roughly meaning the same as sonic geography. Since Rodaway's discussion, the term 'sonic geography' seems to have become more common in the Anglophone community (e.g. Matless 2005; Boland 2010; Boyd \& Duffy 2012; Gallagher \& Prior 2014), but the term 'listening geographies' also emerged (Gallagher et al. 2017), meaning roughly the same as what Rodaway meant by aural geographies.

The choice of the term must not be taken lightly. While 'sonic' refers to sounds themselves - and in consequence their temporality, spatiality, and sociality -, the term 'acoustic' also refers to the physical properties of spaces that affect how sounds are made and propagate (e.g. in terms of echo or resonance), which is important if geographers wish to grasp how spaces shape and change sounds, and how this affects natural ecologies, landscape experience, social relations, political structures, cultural communities, economic spatialities, among others. Both terms may encompass the experience of sounds, so aural, auditory, or listening geographies would be a subfield of sonic or acoustic geographies. On the other hand, other possible terms seem to have been left out, such as noise geographies, or geographies of resonance.

The little agreement over what the field of the study of sound in geography should be called is both a consequence and a reminder that sound has not been a major concern of geographers until recent years. For this reason, while there have been significant theorisations of sound in geography in the last years (Gallagher \& Prior 2014; Doughty et al. 2016; Revill 2016; Gallagher et al. 2017), there is still no significant discussion to how sound has been conceived throughout the discipline's history. In order to tackle this issue, in this article, I approach the different conceptions of sound - and its relations to the underlying scientific paradigms - that emerged through the history of geography. In doing so, I attempt to reunite and compare the conceptions of sound from different times and spaces, as geographical studies on sound are scattered historically and geographically. In the next section, I will address the paradigms that have underpinned geographical research on sound. After this, I briefly discuss the dissonance in the conceptions of sound in geography.

\section{Paradigms underpinning geographical research on sound}

It has often been noticed that the visual has been a hegemonic sense in geography, and that this is the reason why sound has been a poorly studied subject over the course of the discipline (Tuan 1979; Porteous 1982; Pocock 1989; Smith 1997). Despite its marginality in the discipline, sound has been explored by geographers as a spatial, social, cultural and political phenomenon for some time, although this history is often not acknowledged in the reviews of the subject. In this section, I will present three historical moments for the study of sound in geography. First, I will approach the first approaches to sound within regional geography and theoretical geography, which had very different conceptions of sound. Secondly, I will present behaviourist and humanistic approaches to sound that have focused on the perception of sound by humans. Thirdly, I will approach performative approaches to sound including structuralismlpoststructuralism and postphenomenology.

\section{Geography starts to listen}

Sound has been present since the birth of modern geography. von Humboldt (1850), in his descriptions of natural geographic processes, sporadically made reference to the sounds of places, as Malanski (2017) notes. However, the first geographer to have published a study of sound in geography seems to be Granö (1929), with a cartographic study on the sounds of the island of Valosaari in Finland, as Pocock (1989) and Revill (2016) refer. Beyond this contribution, the studies of the paradigm of regional geography have privileged the visual study of landscape. While it has often been argued that the hegemony of the visual is the reason for regional geography to have overlooked sound, it should also be acknowledged that sociological (e.g. Simmel 1981 [1912]) and ethnographical (see Howes 2003; Pink 2009) studies were already approaching the senses and music at the time, so geographers might have taken sound to be outside of the discipline's framework.

Over the course of the twentieth century, the several new paradigms that emerged in geography provided new perspectives on sound. Theoretical or quantitative geography never really grasped the 
issue of sound in a general manner. The few geographical studies under this paradigm occurred late in the discipline and focused mainly on the issue of noise. There are a number of works that were published across Europe during the 1970s. Labasse (1972) studied the geographies of airports and the issues of aircraft noise in European cities. Barceló Pons (1975) attempted to undertake a social geography of noise, as he studied the effects of air traffic noise from three European airports on human health and property values, departing from the studies of noise by acoustic engineers and studies on the effect of noise on real estate by economists. Ohlson (1976), on the other hand, focused on rural landscapes and studied the effects of climatic and topographic elements on the dispersion and level of different sounds. His main concern was however also traffic noise, in this case originating from boats, ferries and snowmobiles.

The conception of sound in these studies is often poorly developed. Sound is reduced to noise, which is defined as a nuisance that can be perceived quantitatively. Sound, therefore, is taken as an abstract entity often reduced to numbers, and understood as objective and homogeneous. That is, this notion of noise cannot conceive different responses to the same sounds, or even differences in sound beyond volume or signal, such as timbre or rhythm. Geographers have since then seldom produced studies on noise, usually traffic-related (e.g. Birnie \& Hall 1981; Kariel 1990; Tadeu et al. 1995; Bennett 1997; Muscar Benasayag 2000; Lam et al. 2010; Szeremeta \& Zannin 2015; Dobryakova \& Kolesov 2016). Once again, a possible explanation for this is the significant development of quantitative approaches to sound and noise in other scientific disciplines, in this case engineering (Ingerslev 1952, 1972; Schultz 1978), architecture (Maekawa \& Lord 1993), and psychology (Kryter 1970). The production on noise or quantitative approaches to sound continues to be dominated by engineers, architects and psychologists to this day (Kang 2007).

\section{Geography listens with people}

In the 1970s, with the advent of behaviourist geography, humanistic geography, and time-geography, geographers were increasingly attentive to the spatial perspective of humans in their everyday life. During this period, a behaviourist approach to sound received some attention in geography, focusing mainly in urban environments. A first seminal study was that of Southworth (1969) in urban planning, who conducted a field study on the perceived variety and character of city sounds and its influence on the perception of the visible city, which provided a starting point for behaviourist geographers. Southworth (1969) based his perspective on environmental psychology, thus establishing a behaviourist approach which was scarcely reproduced over time in geography.

Works that followed this perspective mostly focused on the relation between the perception of sounds and the behaviour of individuals, using quantitative surveys to establish determinist causal relations between certain sonic stimuli and the behaviour of individuals. Some studies have approached how individuals perceive the sonic environment, such as Kariel's (1980) study on the difference in the perception of sounds by mountaineers and the general public, and López Barrio's (2001; López Barrio \& Carles 1997) studies on the sonic environment as a symbolic or signifying medium that influences human behaviour. Others have focused on how the perception of sounds alters individual or collective behaviour. For instance, Hall and colleagues (1981) explored community responses to road traffic and aircraft noise; Lam, Chau and Marafa (2007) researched individual responses to noise in natural spaces; and Boubezari (2003) classified the strategies and techniques that individuals employ in order to seek for sonic comfort. This approach seems to have been abandoned in recent years.

It was with the advent of humanistic geography, which focused on the experience of places, that sound gained a more central role in geographic thought. Tuan's (1974) seminal book on environmental perception, attitudes, and values focused on the senses as the fundamentals of perception, and as such approached hearing. Despite this, Tuan's take on the links between environment, culture, and personal perception and ethics remained primarily focused on visual cues such as landscape, architecture, colour, and symbols. Buttimer $(1976,291)$ also argued that geography needed a "sensitivity to nature, sound, smell, and touch" to grasp the dynamism of the lifeworld, and Seamon (1979) argued that the sound of the rhythms of place, which he called 'place ballets', could invite (or pull away) individuals to participate in social life. 
This interest in sound was certainly not unrelated to the work being done in the emerging field of acoustic ecology at the time. During the 1960s and 1970s, at the Simon Fraser University in Vancouver, a number of scholars, led by R. M. Schafer, created the World Soundscape Project, an educational and research group. The group was concerned with the rapid changes in urban soundscapes, mainly with the increase in noise pollution. Their approach, however, partially differed from the studies on noise by engineers and architects, as they were primarily interested in understanding sound as a quality and not as a mere nuisance. Besides collecting and publishing the recordings of environmental sounds (e.g. World Soundscape Project 1973), Schafer (1977) was dedicated to create and develop a series of concepts to address sound qualitatively, most notably the concept of soundscape (originally presented by Southworth 1969) which refers to the set of sounds hearable at a certain location. For Schafer, soundscapes, like musical works, have a dominant keynote that gives them a sense of place, as well as recognizable soundmarks, which are the sonic version of landmarks. Besides this, soundscapes also contain a series of signals which provide environmental information. This issue was further developed by Truax $(1978,1984)$. The prime method of research developed by the acoustic ecology school was the soundwalk, which are excursions with the purpose of actively listening to the environment (Westerkamp 1974). Schafer's perspective was not only inspirational for geographers, but issues of space and geography were also central to Schafer's perspective on sound (see Schafer 1985). The first geographer to have engaged with the acoustic ecology school was Lowenthal (1975, 1976) on his works on landscape and memory where he questioned the possibilities of recapturing soundscapes from the past.

After the calls of humanistic geographers, a number of geographers engaged in the study of sound as experience, but these also resorted to the concepts and language of Schafer's soundscape studies. The most significant approaches are those by Porteous and Mastin (1985), and Pocock (1989) in English, and by Nogué i Font $(1983,1985)$ in Catalan. Porteous and Mastin (1985) and Nogué i Font $(1983,1985)$ reflected upon soundscape and related concepts, and about how these could be used to expand landscape studies. On the other hand, Pocock (1989) provided a more significant discussion about the study of sound in geography from the point-of-view of experience. Pocock reflected upon different aspects of sounds: its physical and cultural properties, its experience and the role that sound plays in environmental sensitivity, and the difficulties inherent to the description of environmental sound as a non-verbal phenomenon. These insights underpinned studies on sound as an aesthetic property of spaces linked to experience, contemplation, emotion, but also a sense of history (Johnston 1986; Pocock 1987, 1988). Soundscape was understood as the sonic equivalent of landscape, which would be a visual phenomenon. This relation was not criticized during this period, and a multisensorial understanding of landscape (such as the one that can be found in Prior 2017) was absent from these works. Later, Smith (1994) also approached the concept, arguing for a broader attention to sound in space, but with little dialogue with Schafer's arguments.

During the 1980s and 1990s, French geographers, working together with architects and urban sociologists, also engaged with the concepts of soundscape (Cahen Salvador et al. 1980; Augoyard \& Torgue 1995). These works were however more closely related to issues of identity. Amphoux (1993, 2003) worked on the sonic identity of European cities, and Montès (2003) worked on the weaving of sound and collective identity. Amphoux also worked on the application of the concept of soundscape (translated into French as paysage sonore) in urban areas (Amphoux 1997). More recently, in Germany, Wissmann (2014) focused on classifying and mapping types of sounds in urban spaces. The concepts of keynote, signal and soundmark also remain relevant for geographers today when the focus is on aural representations (Wissmann 2008; Wissmann \& Zimmermann 2010; Hones 2015).

\section{Geography listens to everything}

During the 1990s, as geography turned to poststructuralism, attention has turned to the performativity of sound. Rodaway's (1994) reflection on auditory geographies was an important mark insofar as he discussed the concepts of the acoustic ecology school and highlighted its limitations. Rodaway (1994) pointed out that the concept of soundscape is anthropocentric as it focuses on sound from the viewpoint of the human listener. He also criticized the language of acoustic ecology for its proximity to 
visual phenomena; for example it substitutes landscape with soundscape, or landmark for soundmark. Rodaway (1994) argued that it is not accurate to use a visual terminology to address sounds because while visual phenomena tend to be objects for contemplation, the sound experience is more of a "process of engagement with the environment", for three reasons. First, sounds change as individuals move through space. Secondly, sounds may change in the same space over time. Thirdly, the presence of the individual's body always participates in the production of sounds in a given environment. Although he does not propose alternative concepts, Rodaway's criticism of soundscape and related concepts is a significant act during a period in which the focus of social and cultural geographers switches from representation to performance. After Rodaway's work, Smith $(1997,2000)$ was one of the main contributors to think about sound in geography as performance. Although Smith (1997, 2000) focused on music, her discussion of performativity in musical acts was an important starting point to think about the performativity of sound in general. In her study on Renaissance Venice, Smith (2000) argued that performance matters in the study of music, and addressed musical acts in everyday life and ceremonies, and the political, economic and emotional implications of these events. Duffy $(2000,2003,2005)$ was likewise interested in the performativity of music, and studied participation in music festivals as a practice of identity and community. Within this framework of performance, geographical studies start to focus on sounds beyond music, and eventually turned to the nonrepresentational affects of everyday sounds (Anderson 2005; Anderson et al. 2005).

With this, post-phenomenology became the most recent theoretical approach underpinning geographical studies of sound. Post-phenomenology gathered a fair amount of attention by geographers in the last decade (Ash \& Simpson 2016), especially due to the interest in exploring the significance of non-representational phenomena for explaining everyday life practices (Thrift 2011). As the geographical studies of sound started to explore the performativity of sounds, moving away from the study of sound as representation and identity, post-phenomenology became one of the dominant perspectives. The works of philosophers Nancy (2007) and Ihde (2007) on the phenomenology of sound are the most relevant references. Nancy (2007) was concerned with the differentiation of the act of listening from the act of seeing, arguing that while visual forms are objective, persistent and mimetic, the practice of listening is always subjective, resonant, and methexic. Furthermore, he distinguishes between the act of hearing and listening as passive and active forms of the sense. Nancy inverts the common understanding of listening as a distracted form of the sense and hearing as an attentive mode. He argues that hearing, even if in an attentive stance, is the passive mode of the sense, while listening (in French, écouter, which can also mean to eavesdrop, or to spy) is the active mode, when it is attentive to what he calls the 'beyond-meaning' of sound, which is to say the affective and more-than-representational aspects of sound. While Nancy is more concerned with the affectivity of sound, Ihde (2007) worked on the temporality and spatiality of sound. He argues that while sound has been understood by scholars as primarily temporal, it is significant to look at how sound is a product of space, as it emerges from shapes, surfaces, and fields. He approaches the experience of sound as a polyphony which resonates within the subject and shapes the representation of the world in what he calls the 'auditory imagination'.

Simpson (2009) debated the significance of Nancy's perspective to investigate presence and being-with, arguing that thinking about sound leads us to a decentralised subject that is "the relation with others itself". Revill has approached Ihde's thoughts on the auditory imagination, along with Schafer's (1994) and Nancy's (2007) idea of sound as a 'touch at a distance' to argue that sound plays a role in the mediation of social life, as "multiple registers which situate and shape existence and experience [which] can simultaneously help open up the black boxes of both affective and representational political processes" (Revill 2016, 253). To put it simply, postphenomenological perspectives on sound have pointed out that the cognitive-affective state of each individual bodymind is a product of the multiple relations he or she maintains with the environment. In this regard, sound mediates the relation between each individual body-mind and the surrounding environment by transmitting information, meanings, and affects across bodies and spaces. Sonic affects, or sound as affect, becomes a central concept (Duffy \& Waitt 2011; Boyd \& Duffy 2012). It has been pointed out that this means that sound has important social (Boland 2010; Kanngieser 2012) and political (Barns 2014; Waitt et al. 2014) significance, besides its aesthetic role. Within this perspective, 
Gallagher, Kanngieser and Prior (2017) proposed the concept of 'expanded listening' to grasp the multiple effects of sound in the spatio-temporality of social life. Expanded listening "refers to the varied ways in which bodies of all kinds - human and more-than-human - respond to sound", and the purpose of this is to look

"outwards from the dominant anthropocentric understanding of listening, beginning by deepening and expanding human listening (in relation to landscape), then considering how sound moves bodies beyond cochlear listening and human consciousness (as affects and atmospheres), and finally exploring forms of listening in which human bodies are marginal (vibrations in earth materials and machines)" (Gallagher et al. 2017, 618).

This concept has become popular to address the generative role that sounds plays in social interaction and micro-politics, by focusing not only on sound itself, but in how it relates individuals, objects, spaces, and events (MacPherson et al. 2016; Mills 2017; Wilkinson 2017; Kerr et al. 2018; Peters 2018). The intention of going beyond a dominant anthropocentric understanding of listening, however, seems poorly achieved in these studies.

Some authors have employed other perspectives to address sound and listening as performative acts. The works of Waitt with other authors (Duffy et al. 2010; Waitt et al. 2014, 2017) have applied the feminist concept of visceral politics to sound experience. Affect theory (e.g. Massumi 2002; Clough 2007; Gregg \& Seigworth 2010) has also been significant for conceptual advances focused on the atmospheric and affective nuances of sonic environments such as Kanngieser's (2012) and Revill's (2016).

A structuralist/post structuralist approach to sound has also been present in studies that seek to understand the significance of sound for political processes, events, and beliefs. A common philosophical starting point has been the post-structuralist writings of Rancière (2004) on the sensible, and the structuralist/phenomenological writings of Lefebvre (2004) on rhythms. To put it simply, Rancière (2004) advanced the concept of distribution of the sensible which refers to the system of perception and senses that reveals something in common and defines the structure of the parts and positions of what is common, distributing them through spaces, times and activities. For Rancière (2004), the distribution of the sensible creates a regime of identification, that is, it delimits what is visible and invisible, hearable and unhearable, in a common space. He argues that some practices, such as artistic practices, can have a political effect even if they have no explicit political content, because they act on this distribution of the sensible (Rancière 2004, 2011). Revill (2016), for instance, has applied this concept to the geographies of sound. On the other hand, Lefebvre (2004) advanced the notion of rhythmanalysis, that is, the study of bodily and spatial rhythms with the purpose of unveiling how power structures are reproduced in everyday life. He distinguished between cyclical natural rhythms and linear capitalist rhythms, arguing that the former have been progressively substituted by the latter with the aid of modern technologies. His views on the relation between rhythm and social structures have been criticized for its rigidity (Simpson 2008), yet some authors still found his insights on the relation between body, rhythm, and power valid (Edensor 2010; Tiwari 2010; Reid-Musson 2017). While Lefebvre's writings seem to have had a considerable impact on geographies of sound shortly after his work was translated into English (e.g. Simpson 2008; Wunderlich 2010, 2013; Duffy \& Waitt 2011; Boyd \& Duffy 2012; Lehtovuori \& Koskela 2013; Revill 2013), in more recent years his influence seems to have faded. However, in South American geographies, we can observe a growing number of works that mix structuralist and poststructuralist perspectives in the study of inequalities and social divisions regarding sound and sonic spaces (Alves 2013, 2016; Creuz 2014).

These two lines of works - postphenomenological and structuralist/poststructuralist - have been influenced by a number of works in the multidisciplinary field of sound studies that have addressed issues of space and sound (e.g. Carlyle 2007; Goodman 2010; LaBelle 2010; Born 2013; Belgiojoso 2014). Gender and postcolonial perspectives have mostly been absent from the geographies of sound, unlike in the multidisciplinary field of sound studies. A notable exception in gender is Waitt, Harada and Duffy's (2017) recent study on car mobility, where they investigate the feelings of men and women for cars and the motivations for driving them. Saldanha's $(2007,2014)$ long work on musical communities in India is the notable exception regarding postcolonialism. 


\section{Conclusion}

This short overview is a first attempt of writing a history of sound in geography. While it is by no means an exhaustive work, it amplifies for the first time the different perspectives that geography had over sound, a work that had not been done yet. We have seen that throughout the history of geographical research on sound, there have been significant changes in how sound is conceived in the discipline.

In quantitative geography, sound was only thought of as noise - a nuisance that could be reduced to an abstract and quantitative measurement. But in the 1970s, the immense diversity of human responses to sound was approached by geographers through different perspectives. While behaviourist studies privileged the quantitative analysis of perception and behaviour change regarding sound, humanistic geographers were concerned with the overlapping of soundscape and landscape and the experience of both. The marginality of the theme in the discipline meant that the main concepts were being produced by other scholars, and often not thoroughly criticised. This took place only in the 1990s, as the discipline became more interested in performativity, following the emergence of poststructuralism in geography. Since then, the concept of soundscape has been augmented by Central European and South American geographers, while Anglophone geography has turned to a notion of sound as affect and expanded listening.

Probably due to the marginality of the theme in the discipline, the dominant concepts were rarely critically assessed by more recent perspectives (with the exceptions of Rodaway 1994; and Smith 1997), up until recently (Boyd \& Duffy 2012; Bennett et al. 2015; Gallagher et al. 2017; Revill 2016; Prior 2017). For this reason, the conceptual vocabulary of sonic geographies remains scattered and at times unclear. The relations between concepts such as soundscape, acoustics, aurality, noise, silence, and listening must be addressed in further detail if the recently established field of sonic geographies is to have a common language.

\section{Acknowledgements}

I would like to thank Professor Herculano Cachinho for the scientific supervision, and Renato Frias for his help with Brazilian literature. This research was funded by the Fundação para a Ciência e a Tecnologia under grant SFRH/BD/108907/2015.

\section{References}

Alves, C. (2013) Território, música e difusão de informações: o circuito sonoro em Campinas-SP. GEOUSP-Espaço e Tempo 34294-310.https://doi.org/10.11606/issn.2179-0892.geousp.2013.74950

Alves, C. (2016) Geografia dos sons não esquizofônicos na região do Recife: cultura popular e cotidiano urbano. Boletim Goiano de Geografia 36(1) 141-156. https://doi.org/10.5216/bgg.v36i1.40377

Amphoux, P. (1993) L'ídentité sonore des villes européennes. CRESSON, Grenoble.

Amphoux, P. (1997) Paysage sonore urbain: introduction aux écoutes de la ville [CD with text].

Amphoux, P. (2003) L'Identité sonore urbaine: une approche méthodologique croisée. In G. Moser \& K. Weiss (eds.) Espaces de Vie: Aspects de la Relation Homme- environnement, 85-112. Armand Colin, Paris.

Anderson, B. (2005) Practices of judgement and domestic geographies of affect. Social \& Cultural Geography 6(5) 645-659. https://doi.org/10.1080/14649360500298308

Anderson, B., Morton, F., \& Revill, G. (2005) Practices of music and sound. Social \& Cultural Geography 6(5) 639-644. https://doi.org/10.1080/14649360500298282

Ash, J. \& Simpson, P. (2016) Geography and post-phenomenology. Progress in Human Geography 40(1) 48-66. https://doi.org/10.1177/0309132514544806

Augoyard, J. F. \& Torgue, H. (1995) A l'écoute de l'environement. Parenthèses, Marseille.

Barns, S. (2014) Sounds different: listening to the proliferating spaces of technological modernity in the city. Space and Culture 17(1) 4-15. https://doi.org/10.1177/1206331213494733

Barceló Pons, B. (1975) Aproximación a una geografia del ruído. Boletín de la Câmara Oficial de Comercio, Industria y Nevegación de Palma de Mallorca 686-689 57-74. 
Belgiojoso, R. (2014) Constructing Urban Space with Sounds and Music. Ashgate, London.

Bennett, J. (1997) The application of geographic spatial analysis in modeling traffic noise propagation away from a freeway. The Journal of the Acoustical Society of America 102(5). https://doi.org/ 10.1121/1.420736.3

Bennett, K., Cochrane, A., Mohan, G., \& Neal, S. (2015). Listening. Emotion, Space and Society 17 7-14. https://doi.org/10.1016/j.emospa.2015.10.002

Birnie, S., Hall, F. (1981) Indoor noise level limits for residential areas affected by transportation noise. The Journal of the Acoustical Society of America 69(S1). https://doi.org/10.1121/1.386257

Boland, P. (2010) Sonic geography, place and race in the formation of local identity: Liverpool and Scousers. Geografiska Annaler: Series B, Human Geography 92(1) 1-22. https://doi.org/10.1111/j.1468-0467.2010.00330.x

Born, G. (2013) Music, Sound and Space: Transformations of Public and Private Experience. Cambridge University Press, Cambridge. https://doi.org/10.1017/CBO9780511675850

Boubezari, M. (2003) Au-delà du confort sonore; I'usager dans la maîtrise du confort sonore et dans le protocole de mesurage acoustique. Espaces et Sociétés 115 43-60. https://doi.org/10.3917/esp.g2003.115.0043

Boyd, C. \& Duffy, M. (2012) Sonic geographies of shifting bodies. Interference. A Journal of Audio Culture [online 2012] <http://www.interferencejournal.org/sonic-geographies-of-shifting-bodies>

Buttimer, A. (1976) Grasping the dynamism of lifeworld. Annals of the Association of American Geographers 66(2) 277-292. https://doi.org/10.1111/j.1467-8306.1976.tb01090.x

Cahen Salvador, J., Antonioz, B., \& Volfin, M. C. (1980) Paysage Sonore Urbain. Plan-Construction, Paris.

Carlyle, A. (2007) Autumn Leaves. Sound and the Environment in Artistic Practice. Double Entendre, Paris.

Clough, P. (2007) The Affective Turn: Theorizing the Social. Duke University Press, Durham. https://doi.org/10.1215/9780822389606

Creuz, V. (2014) De las voces pasivas al sonido activo: actividades musicales en el circuito superior marginal e inferior en las ciudades brasileñas de San Pablo, Rio de Janeiro, Puerto Alegre, Goiânia y Recife. Estudios socioterritoriales. Revista de Geografía 15 107-132.

Dobryakova, V. A. \& Kolesov, А. А. (2016) ИССЛЕДОВАНИЕ ШУМОВОГО ЗАГРЯЗНЕНИЯ Г. ТЮМЕНИ С ПРИМЕНЕНИЕМ ГИС [A study of noise pollution in Tyumen using GIS]. Interkarto/InterGIS 22(2) $268-273$.

Doughty, K., Duffy, M. \& Harada, T. (2016) Practices of emotional and affective geographies of sound. Emotion, Space and Society 20 39-41. https://doi.org/10.1016/j.emospa.2016.06.007

Duffy, M. (2000) Lines of drift: festival participation and performing a sense of place. Popular Music 19(1) 51-64. https://doi.org/10.1017/S0261143000000027

Duffy, M. (2003) 'We find ourselves again': (re)creating identity through performance in the community music festival. Australasian Music Research 7 103-112.

Duffy, M. (2005) Performing identity within a multicultural framework. Social and Cultural Geography 6(5) 677-692. https://doi.org/10.1080/14649360500258153

Duffy, M. \& Waitt, G. (2011) Sound diaries: a method for listening to place. The Journal of Media Geography VII 119-136.

Duffy, M., Waitt, G., Gorman-Murray, A. \& Gibson, C. (2010) Bodily rhythms: corporeal capacities to engage with festival spaces. Emotion, Space and Society 4(1) 17-24. https://doi.org/10.1016/i.emospa.2010.03.004

Edensor, T. (2010) Geographies of Rhythm: Nature, Place, Mobilities and Bodies. Ashgate, London.

Gallagher, M. \& Prior, J. (2014) Sonic geographies. Exploring phonographic methods. Progress in Human Geography 38(2) 267-284. https://doi.org/10.1177/0309132513481014

Gallagher, M., Kanngieser, A., \& Prior, J. (2017) Listening geographies: Iandscape, affect and geotechnologies. Progress in Human Geography 41(5) 618-637. https://doi.org/10.1177/0309132516652952

Gandy, M. \& Nilsen, B. (2014) The Acoustic City. Jovis, Berlin.

Goodman, S. (2010). Sonic Warfare. Sound, Affect, and the Ecology of Fear. MIT Press, Cambridge.

Granö, J. G. (1929) Reine geographie. Acta Geographica 2 1-202.

Gregg, M. \& Seigworth, G. (2010) The Affect Theory Reader. Duke University Press, Durham.

Hall, F., Birnie, S., Taylor, S., \& Palmer, J. (1981) Direct comparison of community response to road traffic noise and to aircraft noise. The Journal of the Acoustical Society of America 70(6) 1690-1698. https://doi.org/10.1121/1.387234 
Hones, S. (2015) Amplifying the aural in literary geography. Literary Geographies 1(1) 79-94.

Howes, D. (2003) Sensual Relations: Engaging the Senses in Culture and Social Theory. The University of Michigan Press, Ann Arbor. https://doi.org/10.3998/mpub.11852

Humboldt, A. (1850) Views of Nature: Or Contemplation on the Sublime Phenomena of Creation. Harrison and Son, London.

Ihde, D. (2007) Listening and Voice: A Phenomenology of Sound (first edition 1976). Ohio University Press, Athens.

Ingerslev, F. (1952) Acoustics in Modern Building Practice. Architectural Press, London.

Ingerslev, F. (1972) Noise and the sound insulation of buildings. Philosophical Transactions of the Royal Society of London. Series A, Mathematical and Physical Sciences 272(1129) 595-602. https://doi.org/10.1098/rsta.1972.0066

Johnston, R. (1986) Bell-ringing: The English Art of Change-Ringing. Viking, New York.

Kang, J. (2007) Urban Sound Environment. Taylor and Francis, London.

Kanngieser, A. (2012) A sonic geography of voice: towards an affective politics. Progress in Human Geography 36(3) 336-353. https://doi.org/10.1177/0309132511423969

Kariel, H. (1980) Mountaineers and the general public: a comparison of their evaluation of sounds in the recreational environment. Leisure Studies 3(2) 155-167. https://doi.org/10.1080/01490408009512932

Kariel, H. (1990) Factors affecting response to noise in the outdoor recreational environment. Canadian Geographer 34(2) 142-149. https://doi.org/10.1111/j.1541-0064.1990.tb01259.x

Kerr, S.-M., Gibson, C., \& Klocker N (2018) Parenting and neighbouring in the consolidating city: the emotional geographies of sound in apartments. Emotion, Space and Society 26 1-8. https://doi.org/10.1016/j.emospa.2017.11.002

Kryter, K. D. (1970) The Effects of Noise on Man. Academic Press, New York.

Labasse, J. (1972) L'aéroport et la géographie volontaire des villes. Annales de Géographie 81(445) 278-297. https://doi.org/10.3406/geo.1972.18718

LaBelle, B. (2010) Acoustic Territories. Sound Culture and Everyday Life. Bloomsbury, London.

Lam, K.-C., Brown, A., \& Marafa, L. (2010) Deconstructing the spatial-temporal variation of soundscapes in natural areas. The Journal of the Acoustical Society of America 128(4) 2369. https://doi.org/10.1121/1.3508415

Lam, K., Chau, K.-C., Marafa, L. (2007) Characterizing natural soundscapes and understanding human response to human-caused noise in a Hong Kong country park. The Journal of the Acoustical Society of America 121(5) 3161. https://doi.org/10.1121/1.4782229

Lefebvre, H. (2004) Rhythmanalysis: Space, Time and Everyday Life. Continuum, London.

Lehtovuori, P. \& Koskela, H. (2013) From momentary to historic: rhythms in the social production of urban space, the case of Calçada de Sant'Ana, Lisbon. The Sociological Review 61(S1) 124-143.

López Barrio, I. (2001) El significado del medio ambiente sonoro en el entorno urbano. Estudios Geográficos LXII(244) 447-466. https://doi.org/10.3989/egeogr.2001.i244.277

López Barrio, I. \& Carles, J. L. (1997) La calidad Sonora de Valencia. Espacios sonoros representativos. Fundación Bancaja, Valencia.

Lowenthal, D. (1975) The audible past. In International Music Council (ed.) The Canada Music Book 11/12. Proceedings of the Sixteenth General Assembly, 209-217. Canadian Music Council, Montreal.

Lowenthal, D. (1976) Turning into the past: can we recapture the soundscapes of bygone days? UNESCO Courier 29 13-21.

MacPherson, H., Fox, A., Street, S., Cull, J., Jenner, T., Lake, D., Lake, M., \& Hart, S. (2016) Listening space: lessons from artists with and without learning disabilities. Environment and Planning $D$ : Society and Space 34(2) 371-389. https://doi.org/10.1177/0263775815613093

Maekawa, Z. \& Lord, P. (1993) Environmental and Architectural Acoustics. E \& FN SPON, London.

Malanski, L. M. (2017) O Interesse dos Geógrafos pelos Sons: alinhamento teóricos e metodológico para estudos das paisagens sonoras. Ra'e Ga - O Espaço Geográfico em Análise 40 145-162. https://doi.org/10.5380/raega.v40i0.46154

Massumi, B. (2002) Parables for the Virtual: Movement, Affect, Sensation. Duke University Press, London. https://doi.org/10.1215/9780822383574

Matless, D. (2005) Sonic geography in a nature region. Social \& Cultural Geography 6(5) 745-766. https://doi.org/10.1080/14649360500258245

Mills, S. (2017) Voice: sonic geographies of childhood. Children's Geographies 15(6) 664-677. https://doi.org/10.1080/14733285.2017.1287879

Montès, C. (2003) La ville, le bruit et le son, entre mesure policière et identités urbaines. Geocarrefour 78(2) 91-94. 
Muscar Benasayag, E. (2000) El ruido nos mata en silencio. Anales de Geografía de la Universidad Complutense 20 149-161.

Nancy, J.-L. (2007) Listening. Fordham University Press, New York.

Nogué i Font, J. (1983) El paisatge sonor. Per un concepte de paisatge mês ampii. Gra de Fajol 6 4-6.

Nogué i Font, J. (1985) El paisatge sonor de la Garrotxa. Revista de Girona 111 96-102.

Ohlson, B. (1976) Sound fields and sonic landscapes in rural environments. Fennia 148(1) 33-45.

Peters, K. (2018) Sound, Space, and Society. Rebel Radio. Palgrave MacMillan, New York. https://doi.org/10.1057/978-1-137-57676-7

Pink, S. (2009) Doing Sensory Ethnography. Sage, London. https://doi.org/10.4135/9781446249383

Porteous, J. D. (1982) Approaches to environmental aesthetics. Journal of Environmental Psychology 2(1) 53-66. https://doi.org/10.1016/S0272-4944(82)80005-4

Porteous, J. D. \& Mastin, J. F. (1985) Soundscape. Journal of Architectural Planning Research 2 169-186.

Pocock, D. (1987) A sound portrait of a cathedral city [CD]. Department of Geography, University of Durham, Durham.

Pocock, D. (1988) 'The music of geography', In Pocock, D. (ed.) Humanistic Approaches to Geography, 62-71. Department of Geography, University of Durham, Durham.

Pocock, D. (1989) Sound and the geographer. Geography 74(3) 193-200.

Prior, J. (2017) Sonic environmental aesthetics and landscape research. Landscape Research 42(1) 6-17. https://doi.org/10.1080/01426397.2016.1243235

Rancière, J. (2004) The Politics of Aesthetics: The Distribution of the Sensible. Continuum, London.

Rancière, J. (2011) Dissensus: On Politics and Aesthetics. Bloomsbury, London.

Reid-Musson, E. (2017) Intersectional rhythmanalysis: power, rhythm, and everyday life. Progress in Human Geography [online Aug 29 2017] https://doi.org/10.1177/0309132517725069

Revill, G. (2013) Points of departure: listening to rhythm in the sonoric spaces of the railway station. The Sociological Review 61(S1) 51-68. https://doi.org/10.1111/1467-954X.12053

Revill, G. (2014) El Tren Fantasma: arcs of sound and the acoustic spaces of landscape. Transactions of the Institute of British Geographers 39(3) 333-344. https://doi.org/10.1111/tran.12034

Revill, G. (2016) How is space made in sound? Spatial mediation, critical phenomenology and the political agency of sound. Progress in Human Geography 40(2) 250-256. https://doi.org/10.1177/0309132515572271

Rodaway, P. (1994) Sensuous Geographies. Body, Sense and Place. Routledge, London. https://doi.org/10.4324/9780203306864

Roulier, F. (1999) Pour une géographie des milieux sonores. Cybergeo: European Journal of Geography 71 [online Jan 21 1999] http://cybergeo.revues.org/5034

Saldanha, A. (2007) Psychedelic White: Goa Trance and the Viscosity of Race. University of Minnesota Press, Minneapolis.

Saldanha, A. (2014) Dancing outside the city: factions of bodies in Goa. In Gandy, M. \& Nilsen, B. (eds.) The Acoustic City, 108-113. Jovis, Berlin.

Schafer, R. M. (1977) The Tuning of the World. Random House, New York.

Schafer, R. M. (1985) Acoustic space. In Seamon, D. \& Mugeraeur, R. (eds.) Dwelling, Place and Environment, 87-98. Martinus Nijhoff, Dordrecht. https://doi.org/10.1007/978-94-010-9251-7 6

Schafer, R. M. (1994) The Soundscape: Our Sonic Environment and the Tuning of the World. Destiny Books, Rochester.

Schultz, T. J. (1978) Synthesis of social surveys on noise annoyance. Journal of the Acoustical Society of America 64 377-405. https://doi.org/10.1121/1.382013

Seamon, D. (1979) A Geography of the Lifeworld. Croom Helm, London.

Simmel, G. (1981 [1912]) Essai sur la sociologie des sens. In Sociologie et épistémologie. PUF, Paris.

Simpson, P. (2008) Chronic everyday life: rhythmanalysing street performance. Social \& Cultural Geography 9(7) 807-829. https://doi.org/10.1080/14649360802382578

Simpson, P. (2009) 'Falling on deaf ears': a postphenomenology of sonorous presence. Environment and Planning A 41(11) 2556-2575. https://doi.org/10.1068/a41247

Smith, S. J. (1994) Soundscape. Area 26(3) 232-240.

Smith, S. J. (1997) Beyond geography's visible worlds: a cultural politics of music. Progress in Human Geography 21(4) 502-529. https://doi.org/10.1191/030913297675594415

Smith, S. J. (2000) Performing the (sound)world. Environment and Planning D: Society and Space 18(5) 615-637. https://doi.org/10.1068/d225t

Southworth, M. (1969) The sonic environment of cities. Environment and Behavior 1(1) 49-70. https://doi.org/10.1177/001391656900100104 
Szeremeta, B. \& Zannin, P.H. (2015) A percepção dos praticantes de atividade física sobre a qualidade ambiental sonora dos parques públicos de Curitiba-Paraná. Ra'e Ga-O Espaço Geográfico em Análise 33 7-43. https://doi.org/10.5380/raega.v33i0.30969

Tadeu, A., Pereira, A., Lima, J., \& Mateus, D. (1995) Ruído de tráfego rodoviário no Paúl de Arzila. Cadernos de Geografia 14 105-114. https://doi.org/10.14195/0871-1623 146

Thrift, N. (2011) Lifeworld inc. Environment and Planning D: Society and Space 29(1) 5-26. https://doi.org/10.1068/d0310

Tiwari, R. (2010) Space-Body-Ritual. Performativity in the City. Lexington Books, Plymouth.

Truax, B. (1978) Handbook for Acoustic Ecology. Simon Fraser University and ARC Publications, Vancouver.

Truax, B. (1984) Acoustic Communication. Ablex, New Jersey.

Tuan, Y.-F. (1974) Topophilia. A Study of Environmental Perceptions, Attitudes, and Values. Columbia University Press, New York.

Tuan, Y.-F.(1979)Sightand pictures. GeographicalReview69(4)413-422.https://doi.org/10.2307/214804

Waitt, G., Harada, T. \& Duffy, M. (2017) 'Let's have some music': sound, gender and car mobility. Mobilities 12(3) 324-342. https://doi.org/10.1080/17450101.2015.1076628

Waitt, G., Ryan, E. \& Farbotko, C. (2014) A visceral politics of sound. Antipode 46(1) 283-300. https://doi.org/10.1111/anti.12032

Westerkamp, H. (1974) Soundwalking. Sound Heritage III(4) 18-27.

Wilkinson, C. (2017) On the same wavelength? Hyperdiverse young people at a community radio station. Social \& Cultural Geography [online Jul 28 2017] https://doi.org/10.1080/14649365.2017.1358822

Wissmann, T. (2008) The network is us. Podcasting as a chance to connect a scientific discipline. European Geographer 3 41-43.

Wissmann, T. (2014) Geographies of Urban Sound. Ashgate, London.

Wissmann, T. \& Zimmermann, S. (2010) From hear to there. Sound and the cognitive construction of world in popularaudioplays.Erdkunde64(4)371-383.https://doi.org/10.3112/erdkunde.2010.04.06

World Soundscape Project (1973) The Vancouver Soundscape 1973 [CD-audio]. Simon Fraser University, Vancouver.

Wunderlich, F. (2010) The aesthetics of place-temporality in everyday urban space: the case of Fitzroy Square. In Edensor, T. (ed.) Geographies of Rhythm: Nature, Place, Mobilities and Bodies, 45-57. Ashgate, London.

Wunderlich, F. (2013) Place-temporality and urban place-rhythms in urban analysis and design: an aesthetic akin to music. Journal of Urban Design 18(3) 383-408. https://doi.org/10.1080/13574809.2013.772882 